\title{
Äksi nõid - nõukogude aja selgeltnägija
}

\begin{abstract}
Mare Kõiva
Teesid: Artikkel annab folkloori vahendusel ülevaate selgeltnägija/nõiaga seotud juttudest ja tema tegevusest nõukogude ajal, samuti vaatleb konstellatsioone, milles kogukond aktsepteerib erakordse isiksuse. Äksi nõid Hermine Elisabeth Jürgens (1892-1976) on eesti 20. sajandi tuntum selgeltnägija. Tuuakse esile selgeltnägijaga seotud narratiivide peamised teemad ja -motiivid, sh tema isiku folkloriseerumisega seotud juhtumid (Äksi nõiale kanti üle tuntud jutu- ja muistendimotiive). Selgeltnägijaga seotud narratiivid jagunevad suulisteks biograafiateks ja patsiendi- või kliendinarratiivideks. Patsiendinarratiivide hulgas on esiplaanil ennustamislood, kadunud isikute otsimine koostöös ametivõimudega või külastajate palvel, kriminaalide, kadunud isikute, varastatud asjade ja loomade otsimine, abi perekonnaprobleemide puhul ja tuleviku ennustamine; temast kui ravijast on säilinud vähe teateid. Pärast surma sai ta tuntuks Nõukogude Liidu lagunemist ennustava prohvetiseeringuga. Kokkuvõttes on Äksi nõiast rääkiv (patsiendi)juttude kogum huviväärne sissevaade elu võimalikkusse ja argipäeva Nõukogude Eestis.
\end{abstract}

Märksõnad: ennustamisjutud, Hermine Jürgens, moodne nõidus, patsiendijutud, selgeltnägija, Äksi nõid

\section{Sissejuhatus}

Usundilised jutud kajastavad reaalseid kogemusi, arvamusi ja tundeid maagiliste praktikatega kokkupuutumisel ning annavad edasi nende seisukohalt reaalseid tulemusi. Need kogemused puudutavad inimese elu palju emotsionaalsemalt, sügavamalt ja vahetumalt kui seda suudavad edasi anda pelgalt narratiivi vahendid. See iseloomustab ka Äksi nõiaga seotud pärimust. Lisadimensiooni annab pikk elu erinevate poliitiliste võimude ajal. Kuna minu käsutuses on üksnes heterogeensetest allikatest koondatud teave, eeskätt retrospektiivsed patsiendinarratiivid ja folkloristika võimalused fikseeritud uskumuste ja juttude põhjal toimunu tähenduste rekonstrueerimiseks, siis iseloomustan artiklis konstellatsioone, milles kogukonnad, rühmad ja tavalised külaelanikud (mitte 
nõidadesse ega paranormaalsusse uskujad) puutusid kokku ja aktsepteerisid erakordse isiksuse ning missuguseid lugusid temast mäletati.

Õigupoolest on see esimesi katseid analüüsida 20. sajandit mõjutanud ebatavaliste võimetega isikuga seotud jutte - vaatluse all on Äksi nõia ehk kodanikunimega Hermine Elisabeth Jürgensi isikuga (1892-1976) seotud pärimus. Tema elukäigus peegelduvad ebastabiilse ja tormise sajandi keerdkäigud: ta saabus Vene impeeriumi keskusest Peterburi linnast Eestisse, kus elas erinevates paikades. Valdav osa tema Eestis elatud ajast kulges maal, talle võõras elukeskkonnas, kuhu ta viis linlikku mentaliteeti. Kahjuks räägib enamik jäädvustatud lugusid Teise maailmasõja aegsest ja eriti -järgsest perioodist, kui ta oli tuntud oma erakordsete võimete poolest, varasematest aastatest leidub vähe üleskirjutusi.

Hermine Jürgens oli laialt tuntud hüüdnime Äksi nõid all. Sõna nõid on tänaseni mitmetähenduslikuna standardkeeles kasutusel. Nõid märgib üleloomulike võimetega isikut, ravijat, tarka, kuid sõnal on erinevaid konnotatsioone, negatiivseid ja mittenegatiivseid, mis osutavad kokkupuutele tundmatute jõududega, on hinnangulised või markeerivad koguni ebaõnnestumisi. Nagu paljude nähtuste puhul, nii ei puudu ka maagia, nõiduse ja nõidade puhul rahvusvahelised kultuurimõjud. Näiteks on keeles laiemalt levinud fraseologismid nagu igavene nõid, vana nõid, mis tähistavad kurja või kiuslikku inimest, ka väljameelitamisoskustega isikut (Justkui 2002, märksõna nõid). Vanemates fraseologismides ei tule sooline determineeritus selgelt esile, kuid uuemates fikseeringutes iseloomustatakse nõiana pigem naissoost isikut, vanemaid (nais) sugulasi, kolleege, tuttavaid, ülemusi. Sõna paikneb fraseoloogias vandesõnade piiril ja esindab nt tulemuses pettunud isiku hinnangut. Ilukirjanduses seostatakse nõida ravimise, aga ka pahatahtliku maagiaga, rahvateadustes (folkloristika, etnoloogia) oli 19. ja 20. sajandil valdavalt kasutusel lingvistiline etümoloogiline tõlgendus. Selle järgi on sõna semantiline tähendus teadja, šamaan, ja see langeb vähemalt osaliselt kokku rahvapärase seletusmalliga, kus sõna nõid ühendab tervet mõistete kompleksi, semantiliste diskursuste orkestratsiooni. See ühendab sõna teadja, tavatute võimetega või piiripealse isikuga, kes suhtleb üleloomulike ja kardetavate jõududega; agraarses kultuuriruumis omistati nõiale sõnaosavust või nutika manipuleerija omadusi ja muid tähendusi. Nõia kui etniliselt olulise isiku ja etnilise mentaalsuse kandja rolli olulisust rõhutasid nii rahvusliku liikumise eelkäijad (nt Jakobson 1991 [1870] oma Kolmes isamaakõnes, milles ta mõtestas eestlaste ajalugu) kui ka rahvusliku liikumise eestkõnelejad, esimesed arheoloogid, folkloori kogujad ja tõlgendajad, õpikute ja perioodikas ilmunud kirjutiste autorid (vrd Jaan Jung, Jaan Jõgever jt), samuti õpetatud folkloristika esindajad (vrd Oskar Loorits (1928 III: 11, 67 jj; 1952: 476-480)). ${ }^{1}$ Samasugune suhtumine jäi kõlama nõu- 
kogude aja õpetlaste esinemistes, kes esitlesid nõida kui olulist rahvuslike teadmiste säilitajat ja tõlgendajat. Sellest sõltumatult kulges termini elu külades ja linnades, kus nimetuse kasutamine jätkus oma mitmekesisuses, millele lisandusid uued, teistsugustele kultuurilistele tõlgendustele tuginevad, kuid nõia positiivset tähendust rõhutavad diskursused. ${ }^{2}$ Tänapäevalgi kutsutakse tuntud sensitiive ja arstijaid nõidadeks ja selle tiitli ärateenimine tähendab ühtlasi laiemalt tunnustamist, on üks rahvapärase sotsiaalse stratifikatsiooni tunnuseid.

Järgnevalt vaatlen lühidalt Äksi nõia elulugu ja üldisemat sotsiaalset tausta, seejärel narratiivikorpust, keskendudes juttude tuntumatele alateemadele ja motiividele ning narratiivide tunnusjoontele.

\section{Äksi nõia elukäik ja tema kultuuriline suhtevõrgustik}

Hermine Jürgens (snd Blaubrück) oli suhteliselt hea haridusega naine. Ta sündis 1892. aastal Venemaal, Peterburi linnas klaverivabrikandi peres. Ta isa oli sündinud Tartu külje all Kärevere külas, Topa talus. ${ }^{3}$ Gümnaasiumihariduse sai H. Jürgens Peterburis, kus omandas väga hea vene ja saksa keele, samas eesti keelt rääkis ta surmani aktsendiga. Pärast Viiburi muusikakooli lõpetamist (Musiikkiopisto) abiellus ta 18aastaselt kaugsõidukapten Gustav Jürgensiga. Neil sündisid pojad Karl ja Artur. Kui pere sattus majanduslikesse raskustesse, pöörduti tagasi Eestisse, onu tallu Käreveres (tagasituleku ajal oli Eesti veel Vene impeeriumi osa). Eestisse toodi kaasa kaks klaverit ja Bechsteini tiibklaveri abil teenis H.Jürrgens endale elatist kõrge vanaduseni. Mehel süvenes alkoholism, omavaheline läbisaamine oli kehv, ja mees suundus elama Tallinnasse.

Hermine Jürgens oli noorena aktiivne: ta osales rindeõena Vabadussõjas (1918-1920) ja teenis enne Teist maailmasõda elatist kinos, tummfilmidele klaverisaadet tehes, klaveritunde andes, aga enamasti tulevikku ennustades. Mõnda aega elas ta koos tolleaegse kuulsa illusionisti Harri Lindneriga. Enne sõda elas Hermine Jürgens mitmel pool maal koos erinevate meestega. Jürgensi enda sõnul tugevnes tema sünnipärane selgeltnägemise võime kolmekümnenda ja neljakümnenda eluaasta vahel. Põhjuseks olnud selgeltnägemise episood, kus ta 1935. aastal nägi oma elukaaslast (Ahja metsavaht) koos teise naisega. Rahvajutud Ahja kandist räägivad, kuidas mees olnud hädas kurja selgeltnägijast naisega.

Kuigi rahvajutud esitlevad teda ennekõike heasüdamliku naisena, viitavad eluloofaktid komplitseeritud ja tavalisest (isegi linnanaisest) erinevale tüpaažile - äge suitsetaja, kirglik kohvitarbija, paiguti tülitseja (naiskodukaitse organisatsiooni esinaise koha kaotus tüli tõttu). 
1930. aasta lõpus kolis Hermine Jürgens Äksi kanti ja sai seal tuntuks Äksi nõia nime all. Mälestuste kohaselt oli tal väikeses elumajas mõnesajaköiteline raamatukogu, ta luges ja kirjutas palju. Ta oli ka üks neist, kes pidas järjekindlalt päevikut (Grünfeld 2004). ${ }^{5}$

Äksis elatas ta ennast jätkuvalt klaveritundidega, samuti oli ta kiriku organist. ${ }^{6}$ Kuid Teise maailmasõja ajal sai Hermine Jürgens tuntuks just kadunud inimeste otsimisega, millele hiljem lisandus varastatud asjade otsimine. Intervjuud ja arhiivisalvestused esitlevad teda selgeltnägijana, vähem leidub teateid tema kui taimetundja ja ravija kohta. Teadetes rõhutatakse isiksuslikku eripära ja Äksi nõia linlikke maneere. Sellesse loetellu kuulub juba eespool mainitud armastus kohvi vastu ja suitsetamine, sõidud Tartusse kohvikusse või sauna ning kodu sõjaeelset stiili järgiv sisustus. Hermine Jürgensi välimuse kirjeldused on ilmekad ja osutavad, et ta järgis sõjaeelset, esimese vabariigi aegset stiili. Salvestustes märgitakse ka häid suhteid kohalike võimuesindajatega, mis säästsid teda vahel pahandustest, kuid oluliseks peetakse koostööd üleloomulikke võimeid tunnustanud miilitsatöötajatega - kadunud isikute leidmiseks. See on üks 20. sajandi meediumeid iseloomustav motiiv. Viimastel kümnenditel on mitmes riigis valminud samal teemal tõsielusaated ja meelelahutuslikud telesarjad. ${ }^{7}$

Omaette dimensiooni moodustavad viimase saja aasta jooksul meediumite suhted meediaga. Alguses sai nõidusejuhtumitest ülevaate ajalehtedes ilmunud kohtuvaidluste ja kaebuste vahendusel, sajandi viimases veerandis asendusid need portreelugudega.1960.-1970. aastail külastasid Hermine Jürgensit kunstnikud, Tartu ülikooli õppejõud ja üliõpilased, samuti mentaalsete nähtuste olemusest huvitatud isikud. Just kaugemalt saabunud üliõpilased, intellektuaalid ja kunstnikud avaldasid tema eluajal, eriti aga paarkümmend aastat pärast Äksi nõia surma mälestusi oma kokkupuudetest temaga ja tõid esile tema särava isiksuse (Suuman 1974, 2001; Paju 1994; Truus 1999; Talva 2011). Põhjaliku biograafilise materjali koondas ja avaldas raamatuna tuntud keemik Kalle Truus, kellel oli üliõpilaspõlves Äksi nõiaga isiklikke kokkupuuteid. Artikli autori poolt lisandusid K. Truusi väljaandesse tolleks ajaks rahvaluulearhiivi kogutud tekstid, mis andis biograafilise suunitlusega raamatule lisadimensiooni. Äksi nõida tutvustati ka ühes 1990. aastate pikemas telesaates. ${ }^{8}$

Tuleb märkida, et iseseisvumiseelset aega ja selle järgnenud kümnendit iseloomustab pieteetlik ja rahvaarste väärtustav suhtumine. Etniliste väärtuste otsimise, identiteedi ja ajaloo mõtestamise protsessis ülendati rahvaarstid erinevate liikumiste poolt etnilise kultuuri tähtedeks.

Äksi nõia visiidid legendaarsesse Werneri ${ }^{9}$ kohvikusse on mitmetähenduslikud ja avavad laiemaid sotsiaalseid suhteid. Pole kahtlust, et see oli pärast Teist maailmasõda paik erinevate tutvuste loomiseks ja säilitamiseks, kuid 
Foto 1. Hermine Jürgens Tartus Werneri kohvikus. http: / / www.geni.com.

temale ka võimalus oma kunagise elustiili jätkamiseks. Werneris tutvus ta näiteks keeleteadlase ja polügloti professor Paul Aristega, kellega jätkus huvitav dialoog läbi aastakümnete. Paul Ariste esines 1980. aastatel Akadeemilises Rahvaluule Seltsis ettekandega Äksi nõia võimetest ja mõnest oma eksperimendist temaga. Ta oli tavatsenud helistada ja lasta Äksi nõial kirjeldada, mida tema naine parajasti teeb jmt, et jälgida selgeltnägija võimeid. P. Ariste hinnangul võis nõia kirjel-

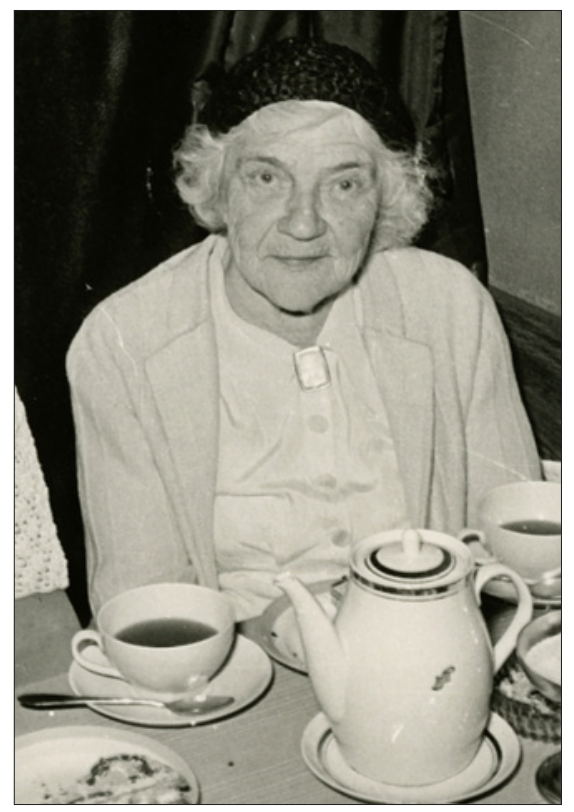
dus märki tabada, kuid ka tühja minna.

Kahjuks olid nõukogude perioodil avaldamisvõimalused kasinamad kui esinemisvõimalused, mistõttu folkloori ja paranormaalsete nähtuste ristumisteemade käsitlused ja materjalikogud jäid avaldamata. Sama puudutab ettekandeid silmapaistvatest meediumitest. ${ }^{10}$ Äksi nõia kohvikututtavatena märgitakse veel nt keeleteadlast Eduard Väärit ja kunstnik Aulin Rimmi (RKM Mng II 4306 < Tartu (1991), Talva 2011).

Suhted partnerite ja poegadega olid H. Jürgensil jahedad; ta suri Kastre hooldekodus 1. juulil 1976 ja maeti Äksi surnuaiale. Hauale pandi tema enda soovil paekivist tahvlike kirjaga “Äksi nõid”. Viimane elupaik, väike elumaja keset viljavälja, üsna maantee lähedal, hävis pärast ta surma nõukogude elulaadile tüüpiliste aktsioonide käigus: maja süüdati tsiviilkaitse õppuste käigus ja põles maha.

Ligi paarkümmend aastat hiljem, 11. juulil 1999 avati kohalike elanike ja teda külastanud inimeste soovil ja rahastusel, aga ka vallavalitsuse ja erinevate fondide toel Äksi nõia viimases elukohas suur mälestuskivi. ${ }^{11}$ Monumendi kujundas pealinna skulptor Ado Koch (samuti isiklikult nõiaga kokkupuutunud isik). Kohaliku kultuuri hoidmisse vastutusega suhtuv raamatukoguhoidja Eve Toots oli üks initsiaatoreid, abistas igati mälestusmärgi valmimisprotsessis, soosivad olid ka meedia kajastused (Jõesaar 1996; Piller 1998; Taal 1999). Kogu mälestuskivi rajamine on suurepärane näide kohalike ja nn välisringi kuuluvate inimeste informaalsest algatusest, millega väärtustati 20. sajandi silmapaistvat alternatiivkultuuri isiksust. 


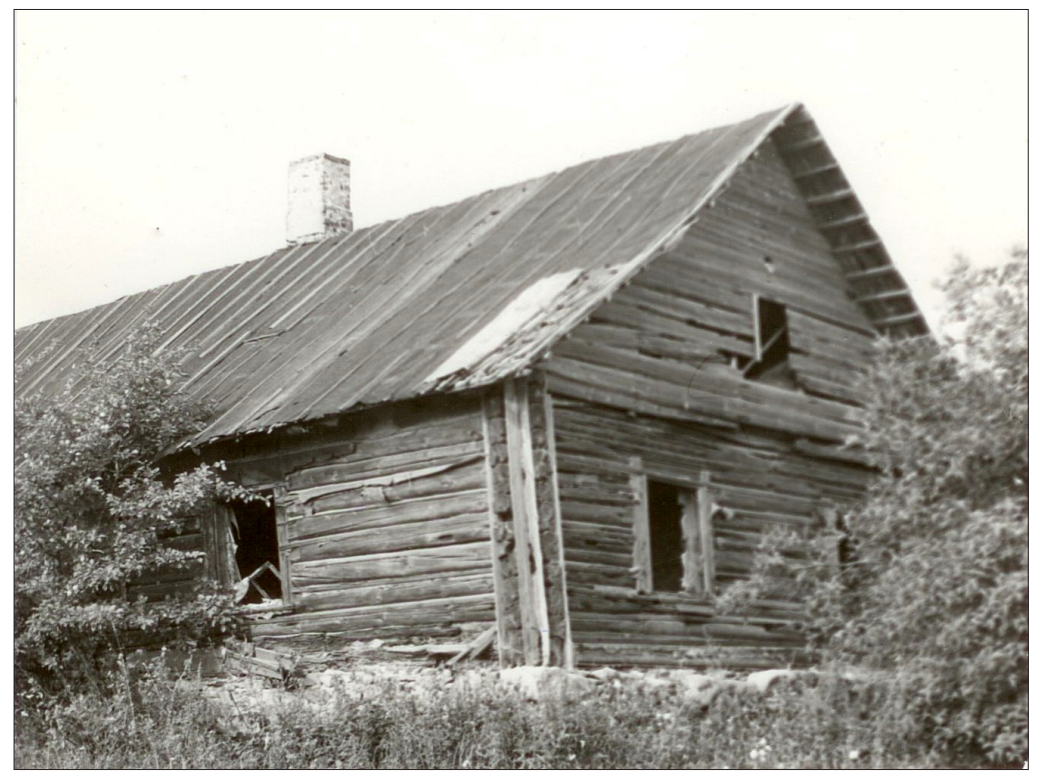

Foto 2. Pärast seda, kui Hermine Jürgens oli läinud hooldekodusse, jäi tema viimane kodu Tartu-Jõgeva tee ääres tühjalt lagunema, kuni lõpuks tuletõrjeõppuse käigus maha põletati. Ain Raali foto.

\section{Jutud Äksi nõiast ja nende ajalooliskultuuriline taust}

Suurem osa Äksi nõida puudutavast folkloorikorpusest on kogutud välitööde käigus pärast tema surma, ennekõike kunagise elupaiga lähikihelkondadest. Äksi elanikke on põhjalikumalt küsitlenud folklorist Anu Korb, kes 1980. aastatel elas Äksis. Lisaks sisaldab tekstikorpus lugusid, mis on esitatud tavasituatsioonides ja saadetud arhiivi kohalike korrespondentide poolt, osa lugusid on aga lindistatud kirjandusmuuseumi külastanud ja selgeltnägijat tundnud inimestelt.

Eraldiseisva kireva kogu moodustavad 1999. aastal mälestuskivi avamisel esitatud meenutuslood linliku eluviisiga naisest. Lindistatu seas leidub unikaalseid motiive, mis osutab, kui oluline on kohalike kirjasaatjate ja lähemate naabrite siseringi vaade. Samuti oli kohalikele elanikele suunatud üritus suurepärane koht lugude salvestamiseks ja uute andmete saamiseks.

Jätsin kõrvale korpuses leiduvad intellektuaalide jutud ja seadsin keskmesse patsiendinarratiivide korpuse, nii suulisest pärimusest kirjapandud kui audiointervjuude kaudu kättesaadava folkloorse teabe. Äksi nõia narratiividest eristuvad lood, kus esitatakse tema lühem suuline biograafia ja andmeid te- 
gutsemisest nõia või selgeltnägijana ning konkreetsete visiitide või kohtumiste kajastused. Palju rohkem kui suulisi biograafiaid on jäädvustatud patsiendi- või kliendinarratiive (mille hulgast eenduvad ennustamislood), väheldane korpus sisaldab selgeltnägija isiku mütologiseerimisega seotud lugusid, sh näiteks tuntud rahvajutu- ja usundimotiivide ülekandeid.

Patsiendi- või kliendijutud on lühemad, harilikult ühe-episoodilised informatiivsed kogemusjutud. Neid on esitatud tõsielujuhtumitena, eeldatavalt ongi tegemist konkreetsete sündmuste ja kindlate inimeste kogemustega, millest on loodud kogemusjutu ääremaile kuuluv narratiivne variant. Ühtlasi on need jutud tihedalt seotud ajalooliste ja sotsiaalkultuuriliste oludega, nad on olustiku- ja faktitruud.

Kuigi Äksi nõid teenis juba enne sõda ennustamisega leiba, muutus ühiskond dramaatiliselt Teise maailmasõja eel, aga eriti selle käigus ja järel. Muserdavale iseseisvuse kaotamisele 1940. aastal järgnes 1941. aasta juunis suurküüditamine. Siberi laagritesse ja asumisele saadeti eeskätt intellektuaale, sõjaväelasi, valitsusliikmeid ja jõukamaid kodanikke. Eestist lahkus selle ja muude sündmuste tõttu Teise maailmasõja ajal ligikaudu kolmandik elanikkonnast, eriti kui selgus, et riigis jääb kehtima nõukogude võim. Pärast Teist maailmasõda oli üks dramaatilisemaid sündmusi 1949. aasta märtsiküüditamine. Uue riigivõimu kiired majanduslikud ümberkorraldused, millega dekonstrueeriti talud, likvideeriti eraomandus ja muudeti kooperatiivide süsteemi jpm, päädisid sunniviisilise üleminekuga ühismajanditele (kolhoosid või leebema majandussüsteemiga sovhoosid).

Milline roll oli neis tingimustes selgeltnägijatel ja nõidadel (ravijatel)? Nõukogude-aegsed sõidud ennustajate juurde linna või maale olid kindlasti 19. ja eriti 20. sajandi alguse tavade jätkuilming. Uutes oludes omandas selgeltnägijate ja ennustajate poole pöördumine siiski sügavama mõõtme, sest valdav oli kadunud inimeste otsimine, mitte kitsalt isiklike tervisemuredega abi järele pöördumine. Selline käik oli võimalus saada vastuseid küsimusele, kas lähedased ja tuttavad on elus ja missuguses maakera osas nad paiknevad.

Sisuliselt igas hõimus jäi küüditamistega sugulasi kaduma ja nende kohta teati sageli üldjoontes, et isik sattus vanglasse või tema üle mõisteti kohut lähem teave puudus. Meeste jäljed kadusid sõjaväeteenistuses või sõjaaegsetel põgenemisteedel, rääkimata tsiviilpõgenikest. Teadmata oli ka metsavendade käekäik, kes olid erinevate mobilisatsioonide eest metsadesse peitunud. Aastakümneid pärast Teist maailmasõda otsiti sugulasi Punase Risti ja mitteformaalsete organisatsioonide vahendusel. Äksi nõid ja temataolised olid habras võimalus lahenduse leidmiseks. Kuigi selgeltnägijate ja nõidade poole pöördus abi järele teatud osa inimesi, on selge, et Nõukogude võimu segmenteeritud informatsiooni levitamine ja informatsiooniga manipuleerimine tõstis alternatiivsete infoallikate prestiiži. 

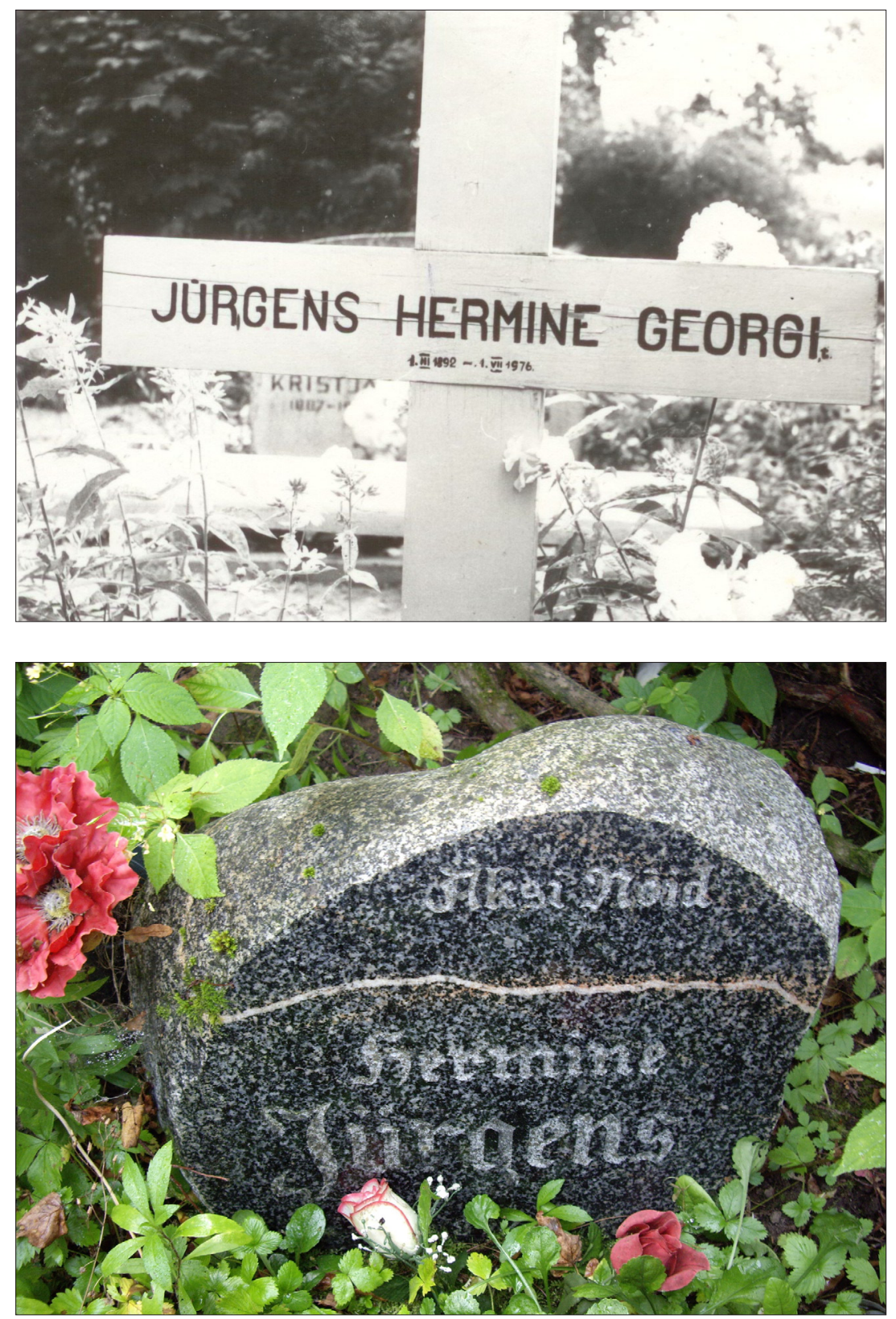

Fotod 3 ja 4. Algselt märkis Hermine Jürgensi (suri 1976) hauda puitrist, 1996. aastal asendati see hauakiviga, millel lahkunu soovi kohaselt ka kiri "Äksi nõid”. Ain Raali fotod. 


\section{Biograafilised lood}

Iseloomustame järgnevalt suulisi elulugusid, mis eristuvad selgeltnägijast rääkivate juttude seast iseseisva jutuliigina. Suulised elulood (või laiemas mõttes genealoogiad) on ilmselt üks vanemaid spontaanse narratiivsuse liike. Inimese elukäik esitatakse neis lühidalt ja üldistustega, fokusseeritakse teatud faktidele ja isiklikele kogemustele, kuid üldistavalt esitatakse nt isiksuse omadused ja harjumused. Äksi nõia puhul üldistavad biograafiad selgeltnägemisvõime avaldumise isiklike kannatuste järel: lapsepõlves vanemate poolt ülekohtuselt koju jäetud laps otsustab vaadata, mida vanemad teevad ja avastab oma võimed. Sagedamini seostatakse tema võimete avaldumist elukaaslases pettumisega.

Ekspeditsioonide käigus kohtavad folkloristid tihti jutustajaid, kelle parim jutuliik on (suuline) biograafia. Folklorist peab mõnigi kord murdma ennast biograafiast läbi, et jõuda kogukonna formeerunud juttude, laulude või väljenditeni. Samas on suulised biograafiad asendamatu liik, kui otsitakse informatsiooni kunagiste laulikute ja pillimeeste, ravijate või kirjasaatjate kohta. ${ }^{12}$ Biograafia juures eendub oskus esile tõsta mõnda eluloodetaili, iseloomujoont või tüüpreaktsioone, võime analüüsida subjekti isiksust ja üldistada inimese käitumist. Tänapäevalgi on peaaegu igas suguvõsas isikuid, kes suudavad esitada pikki genealoogiaid ja konkreetsete isikute elulugusid. Nende naiste ja meeste jututraditsioonis võib olla mitmesuguseid lugusid, kuid kommunikatsiooni tuumliik on biograafia.

Suuline elulugu võidakse esitada erinevates diskursustes. Selleks võib olla (suulise) ajaloo või folkloori diskursus, elulugu võib esitada seostatult erineva kausaalsusega, ajalooprotsessi ja sündmuste keskselt, see võib olla allutatud elamusele või kujundlikkusele jne. Biograafiaid kasutatakse suguvõsasiseses ja territoriaalses suhtlemises, esitatakse pidudel ja kogunemistel, neil on koht generatsioonide vahelises suhtlemises ja igapäevases kommunikatsioonis.

Rahvaluulekogujad eelistavad elulugusid, kus sündmused saavad traditsiooni mudeleid järgiva narratiivse väljundi. Suulise biograafia juurde kuuluvad jutustaja tõlgendused, kommentaarid ja hinnangud. Elulugu võib seega olla jutustusi, hinnanguid jm kooshoidev pilv või kangalõimed.

Kuigi biograafiad võivad sisaldada keerukaid fiktsionaalsuse ja tõepärasuse skeeme, siis näiteks Äksi nõia jutud näivad olevat faktitruud ja tegelikule eluloole lähedased. Läbisaamine külaelanikega polnud Äksi nõial ideaalne, kuid ta on siiski korduvalt neile oma elukäigust rääkinud, mis avaldub ka kirjapanekutest.

Esitan järgnevalt paar eluloojuttu, mis esitati spontaanselt jutustamis-/küsitlemismiljöös, vastuseks intervjueerija pärimisele: Kas te Äksi nõida teadsite? 


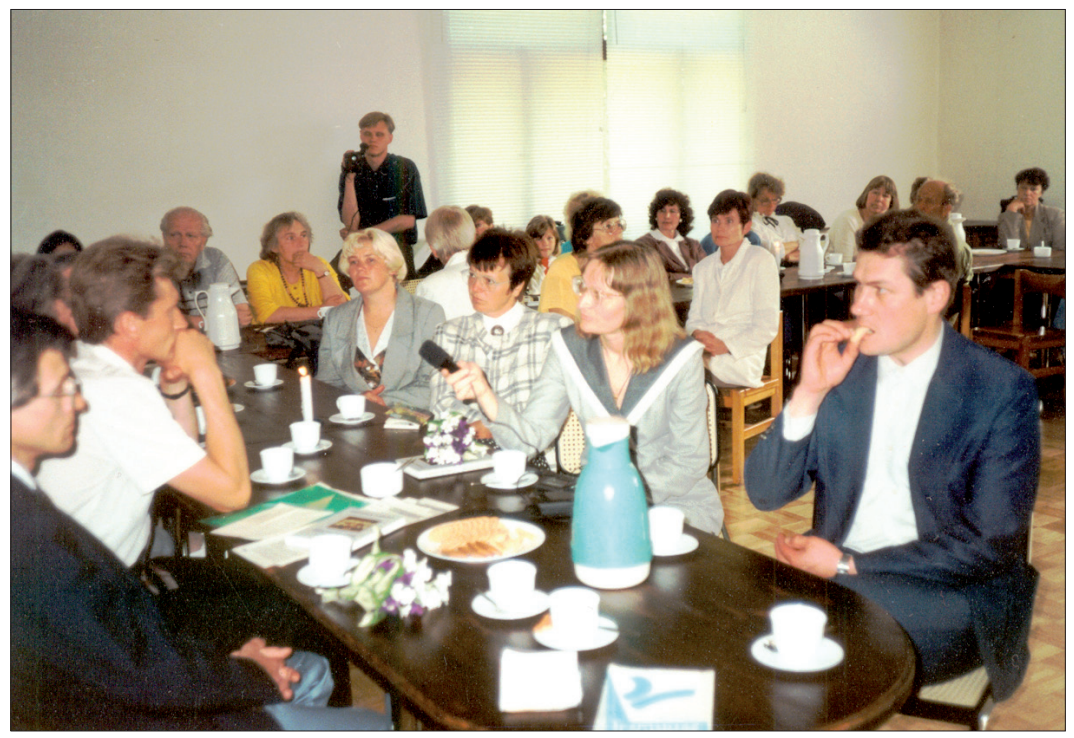

Foto 5. 1999. aasta suvel Äksi nõia mälestuskivi avamisel kõlanud meenutused salvestas lindile Mare Kõiva (pildil mikrofoniga). Foto autori erakogust.

Mõlemad näited on jäädvustatud neli aastat pärast H. Jürgensi surma, tema viimase kodu ümbruskonnast:

Äksi nõid. Jürgens oli ta nimi. Mõni aasta tagasi suri. Ilmast ilma teda taga otsiti, ka pärast surma veel. Nü̈̈d on juba ära jäänud. Isa oli tal klaverimeister. Kiriku heaks kinkis klaveri. Mängis ise väga toredast. Oskas saksa, vene, inglise ja prantsuse keelt. Tal oli suur raamatukogu.

Käis ikka Tartus saunas. Kuumas leilis vihus käsi, et need hästi painduksid.

Nii 1935-36. aastal ta siia Äksi nurka ilmus. Elas mitmetes taludes. Sõprust tal siin suurt ei olnud.

Valgamaalgi käis ja Tartus, võttis ka seal inimesi vastu. Kosti nad talle tõivad. Viimasel ajal ka raha.

Tema oli tark inimene. Rohuteadus oli suur. Ravis jalutuid kõndijaks. Tundis maataimi. [Loetelu haigusi ja nende vastu kasutatud taimi.]

Ta oli selgestnägija. Otsiti teadmata kadunuid ja vargusi. Tüdrukud käisid ka armuasjade pärast.

RKM II 348, 474/5 (31) < Äksi khk (1980).

Teises loos põimitakse eluloojutustusse selgeltnägemise episood. 
Äksi nõid. Tal oli kõrgem haridus. Lõpetanud Peterburi konservatooriumi. Isa oli klaverivabrikant. Andis klaveritunde. Tal oli astroloogiline haridus ja hea meelespidamine. Oskas keeli (soome, saksa, prantsuse, vene), eesti keelt veidi aktsendiga. Ema olnud eestlane, isast ei tea.

Mees olnud laevakapten. 2 poega ka. Mees surnud juba enne, kui ta siia Äksi kanti tuli (umbes 1934-35).

Tema juures käidi palju. Minu ämm ka uskus, käis sinna. Palju honorari ta ei võtnud. Pakk suitsu pidi olema. Toodi toiduaineid (pü̈̈lid, mesi, rasv ja munad). Küpsetas noid kooke hommiku ja õhtu. See oli tema toit.

Kui keegi temalt teateid päris (teadmata kadunute kohta), siis hakkas ennast sisendama. Vaatas toalakke. Siis rääkis. Näit. teeb labidavart, näost kõhna, vast paarinädalane habe ees.

Mina lasin ka tal ennustada. Ennustas, et mees elab, poeg elab. Tegelikult oli juba ammu surnud. Kui ma talle hiljem ütlesin, et ta valesti rääkis, siis ütles: "Kas see oleks siis parem olnud, kui ma oleks ütelnud, et on surnud?"

Tegelikult ikka tühjagi ei teadnud, aga rahvas uskus. Viimane aeg elas Lähtelt siiapoole tulla üksi väikeses majas.

RKM II 348, 477/9 (1) < Äksi (1980).

\section{Patsiendinarratiivid - visiidid selgeltnägija juurde}

Suurim osa lugudest kirjeldab selgeltnägija juures käimist või temaga kohtumist. Narratiiv sisaldab ühe juhtumi, harvem räägitakse mitmest kogemusest. Korpus kirjeldab erinevaid külastamise motivaatoreid ja olukordi, mille pärast teekond ette võeti. Alljärgnevas loetelus eristatakse peamised rühmad ja tuuakse esile, kas käik lõppes positiivse tulemusega ja oli nn edulugu või läks luhta ja oli valelahendusega. Märkigem, et vähesed jutud räägivad luhtaläinud käikudest.

A. Eeskätt räägivad jutud kadunud pereliikmete otsimisest sõja ajal ja pärast sõda, kuni Äksi nõia vanadekodusse minekuni. Esile tulevad küüditamiste ja sõjaga silmist kaotatud sugulaste otsimise lood; enamik jutte räägib täideläinud ja õnnestunud ennustustest, vähemuses on valeennustused. B. Kriminaalsete juhtumite lahendamine - kurjategijate, mõrvarite, kadunud inimeste otsimine (enamasti koostöös miilitsaga); vahelduva eduga lood. C. Varastatud asjade ja loomade otsimine on populaarne teema; abi otsivad nii lihtinimesed kui ka miilits; enamasti on tegemist edulugudega.

D. Abi armuasjades ja perekondade nõustamine; edukus varieerub, sageli loobub nõid abistamast. 
E. Tuleviku ja saatuse ennustamine, kaartidega haiguste ennustamine; enamasti edulood.

F. Narratiivid ravimisest.

G. (Üksikud) poliitilised prohvetiseeringud.

Esimese isiku narratiivide/memoraatide kõrval leidub nn vahendatud, teise või kolmanda isiku memoraate, kus räägitakse teiste kogemustest. Narratiivil on kolm (või kaks) tegelast: jutustaja (külastaja) ja Äksi nõid - kangelase või tähtsaima tegelase rollis. Enamasti eristatakse jutus suhteid jutustaja ja keskse tegelase vahel.

Jutustaja võib olla loos keskne isik ja esindada autobiograafilist "mina". Narratiividel on oluliselt keerukam struktuur, kui peategelane pole jutustaja, vaid teine isik, kuid see iseloomustab konkreetses tekstikorpuses ennekõike fiktsionaalseid lugusid.

Tähtsaim motivaator on enamiku narratiivide juures selgeltnägijalt vastuse/ ennustuse saamine, mistõttu jutu struktuur on lähedane ennustamissituatsioonile. Saabunud külastaja esitab küsimuse ja saab selgeltnägijalt vastuse sümbolite vahendusel, nn sümbolkeeles. Kohase tõlgenduse leidmine on jutustaja/külastaja ülesanne.

Esile tulevad vastandlikud ruumimudelid: jutustaja esitab nõia füüsilise elupaiga (üld)kirjelduse, mis vastandub sümbolite kaudu kujutatud kadunud isiku asukohale. Viimane ruumimudel on hämar ja üldsõnaline, peamiselt kasutatakse tunnussõnu kaugel, külas, metsas, kuskil suures hoones, mere taga jne. Osa tõlgendusi otsekui eeldab ennustuste, unenäoseletuste ja usundiliste narratiivide üldisemate seletusmudelite tundmist. Iseloomulik on ka, et jutus võib jutustaja (kogeja) määratleda (retrospektiivselt) kadunud isiku geograafilise ruumi ja selgitada lahti sümbolid. Kõige olulisem markeerija on narratiivides siiski elus või surnud.

Armilde Pajo kü̈̈ditati 14. juunil 1941 oma vanematega koos Siberisse, aga vend Ants ei olnud tol ajal kodus ja pääses küüditamisest. Kord läks vend saksa valitsuse ajal Äksi nõia juurde, et ehk see teab midagi öelda äraviidute saatuse kohta. Ajasid siis tükk aega juttu ja lõpuks hakkas nõid vahtima toa ühte nurka. Vahib ja vahib ja lõpuks ütles: "Ma näen kaht kalmuküngast ja üht inimest mustasõstrapõõsaste vahel." Sel ajal, kui vend Äksi nõia juures käis, olidki vanemad Siberis surnud ja maha maetud - selleks need 2 hauda. Ja see inimene, kes oli mustasõstrapõõsaste vahel, oli Armilde Pajo ise, kes oli siis perest veel elus, ja kui ta loomadega Obi ääres oli, kasvas seal tõesti mustasõstrapõõsaid.

RKM II 438, 34/5 (23) < Põltsamaa (1990). 
Sageli leidub narratiivis lisateavet Äksi nõia elulaadi kohta, nagu järgnevas ravimisloos:

See oli umbes 1965. aastal. Õppisin sel ajal Tallinnas ning mul oli-eehvaja pöörduda arsti poole - eeh, sest et oli näooperatsioon. See oli tühine asi, aga mille tagajärjel oli nägu kinni plaasterdatud ja. Ja siis kui pidin ma saama igasuguseid tablette, et veremürgitus ei läheks edasi ja.

Ühel päeval, siis kui ma olin jällegi tablette võtnud ja olin Werneri kohvikus, pöördus üks vana daam minu poole küsimusega, et mis mul siis viga on. Noh, ma siis seletasin temale ära, mis mul viga on, sest näo järgi ma seda daami tundsin ja tema tundis ka mind. Olime sõitnud väga palju koos Saadjärve, Jõgeva ja kõigi nende bussidega Tartusse. Ja nii ma siis esimest korda sain isiklikult tuttavaks proua Hermiine Elisabeth Jürgensiga ehk nagu kohalik rahvas kutsus teda, Äksi nõiaga. Proua Jürgens käis igal reedel Werneri kohvikus ja sealt minnes läks ta Emajõe sauna. See oli täieline, täielik traditsioon, mida ta kunagi ei rikkunud, välja arvatud muidugi siis, kui ta oli juba nii vana, et ta ei suutnud seda teha. Werneri kohvikus ootasid teda kõige lähedasemad tuttavad: Paul Ariste, eeh, siis oli Eduard Vääri ja kunstnik Aulin Rimm. Need siis tulid, tervitasid, vestlesid ja suhtusid temasse äärmise lugupidamisega. RKM Mng II 4306 < Tartu (1991).

Kadunud loomad ja hinnalised esemed olid tähtsad nõia külastamise põhjused. Neistki ennustustest rääkivates narratiivides eenduvad kujukad detailid:

Äksi nõid aitas ka varguste koha pealt. Siinsamas talus. Västrikul varastati lehm ära. Miilitsaga otsisid. Lehm pidi varsti poegima. Vana Mann käind nõia juures. Nõid rääkind ja vahtind: Naisterahvas lüpsab, valge rätt peas, on savilaut.

Taga Tartu, kus lehm oli, naine lüpsnudki, valge rätt peas. Miilits tõigi lehma ja vasika ära.

RKM II 348, 443 (39) < Äksi khk (1980).

Järgnev jutt käsitleb Äksi nõia võimeid. Iga ajastu iseloomustab selgeltnägijaid, ravijaid ja nõidu eripäraste mõistete abil. Üks nõukogude aja tüüpväljendeid üleloomulike võimetega või sensitiivsete inimeste kohta oli kuuenda meele omamine, seda kohtab ka neis juttudes. Osa jutustusi kirjeldab lähemalt ennustamistoiminguid ja edastab selgeltnägija enda seletusi oma võimete ulatuse või piiratuse kohta: teda väsitab näiteks informatsiooni otsimine füüsiliselt kaugel paiknevate isikute kohta ja surnuid ta omasõnutsi ei näe. 
Tal oli tõepoolest see kuues meel. Nägi oma vaimusilmas seda, mida teised ei näe. Tema käest käidi abi otsima teadmata kadunute leidmiseks, samuti varguste asjus.

Kui see, kelle järele päriti, oli väga kaugel (näit. Jaapanis), siis nõid ütles: "See käib mu tervise peale. Väsitab mu ära."

Kui inimene, kelle järele päriti, oli surnud, vastas Äksi nõid: "Ma ei näe teda."

RKM II 348, 443/6 (1) < Äksi khk (1980).

Vastakad on teated peretülide ja tulevase elukaaslase ennustamiste kohta: kui osa jutustajaid väidab, et ta abistas selliste probleemidega saabunuid, siis teine osa kinnitab, et tavakohane vastus oli: "Seda peate ise teadma."

Äksi nõia haridust ja linlikku tausta arvestades võib eeldada, et tema teadmised põhinesid suuresti trükistel ja vähem perepärimusel. Ta koduse raamatukogu koosseisu on võimatu pika aja tagant määrata, kuid maagiaraamatute ja muu tarbekirjanduse omamisele on intervjuudes viidatud: "Tal oli palju raamatuid. Üks prantsuskeelne raamat oli vasaku käe kohta (käejooned)." Sõjaeelsetes Eesti trükistes ja perioodikas avaldati meelelahutuseks käevaatamise tarkusi, ilmusid taimravi, maagia ja astroloogia käsiraamatud jpm (lähemalt nt Annus 1993; 1995). Käevaatamise kõrval on Äksi nõid pannud kaarte (seda oskust mitmed kirjasaatjad eitavad, tuntav on kaardiennustaja madalama kategooria teadjaks pidamine), tundnud astroloogiat ja koostanud horoskoope. See oskus oli nõukogude ajal hinnas, sest isiklikku mahukamat horoskoopi oskasid koostada vähesed.

Esile kerkivad ka kaks indikaatorteemat: suhted arstidega (neid hinnatakse headeks), teda asetatakse koguni eksperdi rolli ("Isegi arstid tunnistasid ta teadmisi. Teda kutsuti Tartusse sapi-, põie- ja neeruhaigeid vaatama." $)^{13}$ ja tasu võtmise küsimus. Suuline reeglistik piirab arstimise eest tänamise (edendab haigusi, takistab tervenemist) ja sätestab peamised reeglid tasu või sellena toodud kinkide vastuvõtmise kohta - tasu on endal keelatud küsida ja Äksi nõid näib olevat neid reegleid järginud. Lugudes viidatakse ennekõike toiduainete (toidukaupadest peamiselt leib, piim, munad) ja suitsupakkide vastuvõtmisele. Rõhutatakse, et ta saatis vahel osa kohaletoodud meeleheast tagasi või küpsetas endale toodud ainetest hommikuks ja õhtuks kooke jm oma eluviisile vastavat.

Haiguste ravimine, eriti taimetarkusega, moodustab suhteliselt tagasihoidliku osa ja ajaliselt pärinevad sedalaadi teated Teise maailmasõja järgsest perioodist. Teda peetakse herbalistiks, kirjeldatakse ravimeetodeid, kuid viidatakse ka sõnadega ravimisele. 
Äksi nõid tegi kõike. Ravis inimesi ka. Posimissõnad luges peale. Aitas küll. Kokuta Marie kunagi Äksi nõia käest sai need kaarditarkused. Äksi nõid oli ligi 90 ringis, kui suri.

RKM II 430, 432 (20) < Kursi (1989).

Lähemalt iseloomustatakse ka taimede korjamise oskusi ja sobivate ajaankrute valimist, nagu kuufaas ja päevaosa; taimi sisustuse osana ja muid teemasid. Järgnev tekst annab sissevaate herbalisti-teadmistest.

Tundis rahvameditsiini. Kuivatas toas ravimtaimi, pressis neist mahlu välja. Teadis, millal koguda, millal miski taim kõige paremas õitseeas on. Üks tuba oli tal täis kõiksugu juurikaid, pungi ja lehti. Äksi nõid ütles, et tilk tema rohtu on parem kui liiter valel ajal korjatut. Ravimtaimede korjamisel pidi olema tähtis kuufaas, kellaaeg. Ta võis ööselgi korjata, kui vaja. RKM II 480, 123 (11) < Tartu (1983).

Skeptilised lood selgeltnägijate ja rahvaarstide ebaõnnestumiste kohta on vastava pärimuse osa ning seetõttu pole üllatav ka katsetamine Äksi nõia võimetega. Esineb ka narritamisjuhtumite kirjeldusi, näiteks on kohalikud käinud teatamas, et teda oodatakse jaamas ning itsitanud, kui selgeltnägija otsib olematuid külalisi.

\section{Fiktsionaalsed lood, tuntud folkloorimotiivide ülekandumine}

Nõia saatusest rääkivad lood toovad esile üleloomulikud seigad ja võimete tavatu avaldumise, mis toob eeldusena kaasa (vähemalt surma eel) karistuse oma tegevuse eest. Sellesse korpuse ossa kuuluvad ka mõisted üksindus, raske üksildane suremine jm (vrd Loorits 1951: 482 jj), mida rahvapärimus seostab nõia saatusega. Tema kui tuntud isikuga on seostatud varasemaid tuntud jutumotiive, mis annab põhjuse rääkida tema isiku folkloriseerumisest. Ilmekas on kuulsa Lõuna-Eesti nõia Suriga (Kusta Taits, sama nime all oli tuntud tema poeg Anton Taits $)^{14}$ seotud muistend, nn munalugu, milles patsiendi toodud kanamunad muutuvad ussideks (Suriga on seotud üle seitsmekümne variandi, vt lähemalt Kõivupuu 2000). Suri külastaja ei raatsi talle tasuks anda kõiki kaasavõetud mune, peidab need põõsa alla. Koduteel neid võtma minnes leiab ihnur, et munad on muutunud rästikuteks, nagu nõid ennustas. 1970. aastatel on munalugu seostatud ka Äksi nõiaga, tihti on need esimese isiku memoraadid, erinedes sellega vanematest Suri lugudest.

Minu onu, ema vend läks sinna Äksi nõia juurde, olime hobusega. Ema oli ja mina olin kaasas, olin vist kuue-aastane. Temal olid kanamunad 
kaasas ja onu ütles, et ära vii talle mune. Pane sinna silla alla, kuulame enne ära, mis loo ta meile räägib.

Nõid rääkis oma jutu ära ja ütles, et: Kui tagasi lähete, võtke see ussikomps sealt ära. Läksime tagasi ja olidki maduussid seal sees. Ema läks mune võtma ja kohe kiljatas.

RKM II 447, 121 (8) < Torma khk (1991).

Äksi nõiaga seostatakse ennustust, mille järgi Eesti saab vabaks, ent Venemaa jääb nii väikeseks, et Kremli aknast näeb Venemaa piiri. Täpsem ütlus varieerub pisut. See oli üks temaga seotud leitmotiive 1980.-1990. aastatel ja muutis ta taas üldtuntuks. Ütlus kuulub siiski 19. sajandi kuulsale prohvetile, paljude sotsiaalsete prohvetiseeringute autorile Järve Jaanile (Kõiva 2010: 20). Erinevad meenutused on toonud esile teisigi prohvetiseeringuid seoses eesti vabanemise ja omariiklusega. ${ }^{15}$

Ka nõia surmaga on seotud mitmed laiemalt tuntud folkloorsed motiivid (meenutan, et tal oli kaks poega) - üks neist soov saada maetud koos tütrega:

Äksi nõid. Kui haigeks jäi, oli kellegi juures korteris olnud. Öelnud peremehele: "Kui ära suren, mata sina mind ära ja tütar minu kõrvale."

Mees vastu: "Sul on ju tütar elus, kes sind matab!"

Nõid ikka: "Ei, mata sina! Ma ei saa surra, kui sa ei luba!” Mees andiski siis lubaduse.

Tütar läks emale puusärki tooma. Sai tee peal surma. Tuligi ühte hauda matta.

RKM II 431, 140a/1a (52) < Palamuse khk (1989).

\section{Kokkuvõtteks}

Äksi nõid oli üks 19. sajandi lõpus ja 20. sajandil tegutsenud selgeltnägijatest ja ravijatest, kes jätkas tegevust Nõukogude Eestis. Igal arstijal ja selgeltnägijal on folkloorsete lugude kese. Võrreldes omavahel Suride ja Äksi nõia kohta levinud folkloori, leiame sarnaseid jooni narratiivsuses ja uskumustes. Rahvajutukataloogi tüübiloetelud osutavad sarnastele tüüpidele (selgeltnägija (Jauhianen 1999: D 601, D 1501); varguste lahendamine (Jauhiainen 1999: D 621, D 691); tuleviku ennustamine (Jauhiainen 1999: D 1501-1600), mis Suridest rääkiva pärimuse puhul on palju pikem, keskendub ravivõtetele ja haiguste ravimisele (vt lähemalt Kõivpuu 2000). On aga selge, et Äksi nõia pärimuses eenduvad kadunud isikute otsimise lood, mis Suride juures on üksnes lugude ääreala, ajastu tellimus. Samas on H. Jürgensi ravimise kohta säilinud pärimus napp ja üldsõnaline, enamasti isegi üksnes loetlev. 


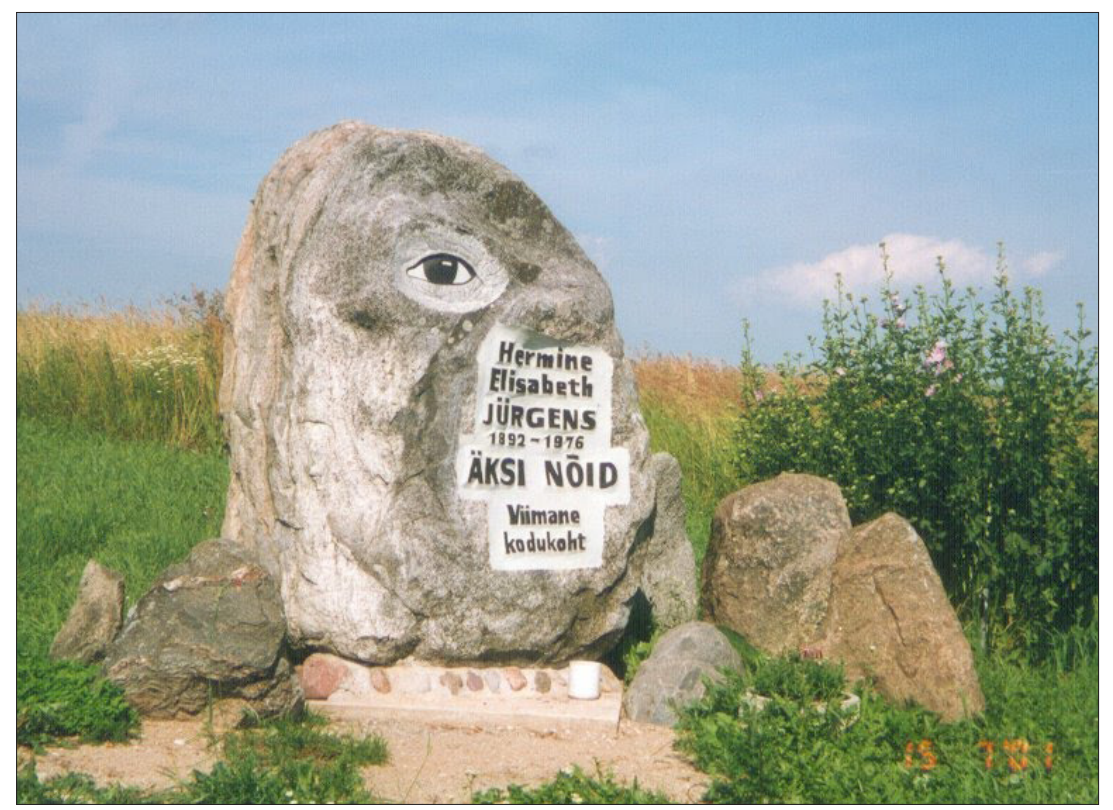

Foto 6. Mälestuskivi Äksi nõiale tema viimase kodu asemel Puhtaleiva külas Tartu-Jõgeva tee ääres. Kalle Truusi foto 1999.

Ühegi isiku olemus ja tema tegevus ei taandu narratiivsetele tüüpidele, vaid on oluline elatud elu võtmes. Täpsema ülevaate loomine Eesti rahvaarstidest ja nende tegevusest seisab ees ja see pole kerge ülesanne, arvestades, et neist, aga eriti ennustajatest ja selgeltnägijatest on arhiivis vähe ainestikku ning valdavalt on tegemist patsiendi vaatega juhtumile.

Praegu on võimalik Virumaa, Tartumaa, Võrumaa ja Saaremaa ainestiku näitel üldistada, et kohapealsete ravijate dünastiate esindajad jätkasid nõukogude ajal traditsiooniliste võtetega arstimist, kuid oli ka uusi ametisse hakkajaid väljastpoolt tuntud perekondasid. Eelmise sajandi jooksul kasvas nn maailmas rännanud ravijate osakaal, kes tõid ravimisviisidesse uuendusi. Neist osa liikus ameti tõttu ringi (nagu mitmed Sõrve meremehed-ravijad), osa lahkus parema elu otsingutel Eestist ja naases Venemaal puhkenud revolutsiooni, näljahäda või optsioonivõimalustega Eestisse, nagu mitmed Võnnu ümbruses tegutsenud ravijad (nimetagem nt Lehti Solnat) ja saarlane Tiitsu Seiu. Tingimisi kuulub sellesse kategooriasse ka Äksi nõid, kellel oli valdavast enamikust ravijatest parem haridus ja jõukam linlik päritolu.

Tuntud ravijatest tuli segastel aegadel vabatahtlikult Saaremaale tagasi Tiitsu Seiu (Aleksei Lesk) - lombakas vaese pere poeg, kes rätsepaks õppimise 
järel (selle ihuveaga maalt pärit laste üks väheseid elukutseid) lahkus kodust. Liepajast saabudes ostis ta talu ja jätkas võimaluste piirides rätsepa ja taluomanikuna, ravimine kujunes lisaametiks ja eksperimenteerimise valdkonnaks. Tiitsu Seiu rahvaluule arhiivi saadetud kirjad peegeldavad raskusi kohaliku külaelu ja selle mentaliteediga kohanemisel pärast aastakümneid linnaelu, ravimist jätkas ta vaatamata võimuvahetustele (Kõiva 1989).

Lood Äksi nõiast näitavad linnamaneeridega isiku kohanemist eluga maal ja võõrastes sotsiaalpoliitilistes oludes, kriisisituatsioonis kasutatud strateegiaid, selgeltnägija koostööd võimudega, samuti tuntud jutumotiivide ülekandumisest Äksi nõiale.

Selgeltnägija elust ja tegevusest rääkivates narratiivides põimuvad fiktsionaalsus ja mittefiktsionaalsus, ehkki tõsielu kogemusel põhinevaid lugusid on enim. Patsiendi- ja ennustamisjutud peegeldavad aktuaalset sotsiaalset situatsiooni ja vahendavad reaalseid kogemusi (vrd Kulli 2002). Ühtlasi annab Äksi nõia lugu huvitava sissevaate ellu Nõukogude Eestis. Näeme, kuidas oli võimalik ennast elatada selgeltnägija ja ravijana, ehkki selline tegevus polnud soositud ega lubatud, ent tema külastamist tingis otsene vajadus.

Äksi nõid jätkas Teise maailmasõja eelset ennustajate traditsiooni, õppides juurde erinevaid võtteid ja laiendades oma oskusi. Samas jäi ta hoiakutelt ja käitumiselt esindama sõjaeelset Eestit, olles sotsiaalsetes oludes adapteeruja ja oma valitud joone jätkaja. Tema välimuse kirjelduses korduvad iseloomustused: lühike lokkis juustega ja kübaraga (tante). ${ }^{16}$ Samuti tuuakse esile suitsetamist, mis enne ja pärast Teist maailmasõda polnud naiste seas eriti levinud, vaid oli ennemini linliku ja parema haridusega isikute moejoon, mis polnud enne ja pärast Teist maailmasõda naiste seas laiemalt levinud, ${ }^{17}$ muusikaannet ja häid suhteid erinevate õpetlaste, linlaste, võimudega. Omapäraste kinnistavade hulka jäävad Tartus kohvikus ja saunas käimine. Kindlasti saanuks sauna ka Äksis, aga ehk oli see võimalus kohtuda vanade tuttavatega Emajõe saunas? Või olid need käigud sõõmuke värsket õhku?

Hermine Jürgens väärtustas nõia rolli. Seda toetas kogukonna soov ja tahe teda sellisena mäletada. Iga ameti pidaja juures on olulised tema motivatsioon, panus kogukonda ja isiklik eetika. Neist ühegi kohta pole Jürgensi puhul üheseid vastuseid, sest paljudele küsimustele on nappide andmete tõttu aastakümneid hiljem keerukas vastata. Ent kindlasti oli tema motivatsioon laiem elatise teenimisest ja panus kogukonda oluline ravijana, ennekõike aga selgeltnägija ja inimestele tasakaalu pakkujana.

Kogukond mäletab teda kui selgeltnägijat ja imepärast kadunud isikute otsijat, aga ka talle Nõukogude Liidu lõppu kuulutava ennustuse omistamise tõttu.

Uus periood nõukogude-aegses rahvapärases ja alternatiivses arstimises algas küüditatute tagasisaabumisega 1956. aastal ja hiljem. Eeskätt uutel 
kultuurikontaktidel põhineva arstimiskogemuse saabumine Eestisse, samuti teisest rahvusest rahvaarstide Eestisse elama asumine ja regulaarsed visiidid tõid kaasa olulisi uuendusi.

\section{Kommentaarid}

1 Oskar Loorits eristas termineid nõid/loitsija ja ravija, tark, doktor; ta üldistab, et termin nõid tähistas varem mehi, šamaani staatuses isikuid (Loorits 1952: 480). Üks tüüpilisi kokkuvõtlikke tänapäevaseid seisukohti on järgnev: "Nõid oli ju vanasti eesti keeles targa sünonüüm," alustab ta kaugemalt. "Alles keskajal, tänu kristlusele, sai see sõna negatiivse tähenduse. Mina pole mingi nõid või tark, ainult lugenud ehk natuke rohkem" (http://arhiiv.elukiri.ee/index.php?main=355\&sess=). Nõia-nimetus ja selle ajaloolised tõlgendused vajavad edaspidi pikemat käsitlust.

2 New Age liikumises keskne nõid sobis ideaalselt eesti rahvuslike seletuste, õpetatud ja rahvapäraste seletusmallidega.

3 Eesti oli sel ajal Vene impeeriumi osa.

4 Äksi on Tartumaal asuv endine kihelkond, mis asub Saadjärve lõunakaldal, umbes 20 km Tartust. Teise maailmasõja ajal elas seal 200 inimest. Äksi oli 2010. aastani ka küla, Äksi kihelkonna keskus, kus asus ka kirik. 2010 sai Äksi külast alevik.

5 Ajakirjanik Inna Grünfeldti intervjuust biokeemik Aili Pajuga selgub, et viimane toonud Tartusse kirjandusmuuseumi kultuuriloolisse arhiivi Äksi nõia päevikutest tehtud mikrofilmid, mis läksid muuseumis kaduma (Grünfeldt 2004). Võimalik, et neid ei võetud nõukogude perioodil tsensuurihirmus arvele ja nad on kuskil fondihoidlates alles. Samas oli mikrofilmimine sel ajal piiratud ja reguleeritud tegevus ning eeldas häid sidemeid laboratooriumitega. Teateid Äksi nõia päevikute lugemisest on teisigi.

6 Biograafilised andmed põhinevad andmebaasil Geni.com (Hermine Jürgens) ja Kalle Truusi raamatul.

7 Vaidlused meediumite kohtuprotsessidesse ja kriminaaljuhtumite lahendamisse kaasamise teemal on kestnud üle poole sajandi. Ehkki teaduslik kinnitus puudub, jätkub meediumite appi kutsumine. Nähtust fikseerivad või meelelahutussaated on viimase poolsajandi meediaformaadid.

8 Telesaade oli lahendatud Tartu Werneri kohviku toel ja sisaldas mäletusi Äksi nõia kui kuulsa kohvikukülalise visiitidest.

9 Werneri kohvik tegutseb alates aastast 1895.

${ }^{10}$ Paranormaalsete nähtuste kohta kogus 1970. aastate alguses andmeid (õigupoolest lugusid) mitmekülgsete huvidega psühhiaater Ilmar Soomere (snd 1942). Sellest kujunes üks suuremaid ja materjalimahukamaid tolle aja kogumisaktsioone, millest vormus mahukas käsikiri 1000 parajuhtumit Eestis. Käsikirja üks eksemplar oli hoiul nt kirjandusmuuseumi rahvaluulearhiivi käsikirjaliste uurimistööde kogus. Trükist ilmus raamat alles 1997. aastal pealkirja all 800 parajuhtumit Eestis (Soomere 1997). Konkreetselt Äksi nõia kohta on mäletamisi koostatud üks üliõpilastöö, samuti esinetud erinevatel konverentsidel (Kõiva 2010).

11 1990. aastad olid oluline alguspunkt rahvuskultuurile oluliste sümbolite, isikute ja paikade määratlemise protsessis. 
${ }^{12}$ Rahvaluulekogumise ajaloo jooksul on korrespondentidelt korduvalt küsitud autobiograafiaid ja portreefotosid. Esimesena palus kirjasaatjatel kirjutada autobiograafia rahvaluule kogumise suurkuju Jakob Hurt. Saadud (eeskätt 19. sajandi lõpul laekunud) lühemad elulood on ulatuslik omakäeliste kirjalike elulugude kogu, mille muudavad huviväärseks neis formuleeritud valikud, motivatsioonid ja väärtushinnangud. Ka hiljem on rahvaluulet kogunud institutsioonid palunud kirjasaatjatelt elulugusid, samuti on esitatud lisaküsimusi kogumisstrateegiate kohta.

${ }^{13}$ Eksperdina toimimine ("Isegi arstid tunnistasid ta teadmisi. Teda kutsuti Tartusse haigeid vaatama.") on intervjuudes tüüpiline ülistav kokkuvõte ka teiste tuntud rahvaarstide-selgeltnägijate kohta.

${ }^{14}$ Eesti keeles puudub sookategooria, nõid märgib nii mees- kui ka naisnõida. Suri kohta on põhjaliku käsitluse avaldanud Marju Kõivupuu (2000), seal on puudutatud ka muna-lugu.

${ }^{15}$ Ennustusel on mitmeid variante, Ingvar Luhaäär kirjutab: "Äksi nõia selgeltnägemisvõime kõige säravamaks pärliks on kahtlemata ta ennustus, et Eesti saab vabaks varsti pärast Saksamaa taasühinemist" (Luhaäär 2014).

16 Tante, tanta - arhaism, saksalaenuline vaste sõnale daam.

${ }^{17}$ Kunstis levis suitsetava naisefiguuri kui vabaduse sümboli kasutamine 1930. aastatel. Eesti täiskasvanud rahvastiku tervisekäitumise uuringu 2010. aasta andmetest nähtub, et $18,7 \%$ naistest on igapäevasuitsetajad ja 7,3\% juhusuitsetajad. Tütarlaste ja noorte naiste seas, vanuserühmas 16-24 aastat on igapäevasuitsetajaid 19,9\% ja juhusuitsetajaid $12,4 \%$ (2008. aastal vastavalt $13,6 \%$ ja $12,3 \%$ ) ning $25-34$ aastaste naiste seas on igapäevasuitsetajaid $16,5 \%$ ja juhusuitsetajaid $6,4 \%$ (2008. aastal vastavalt $15,8 \%$ ja $7,6 \%)$.

\section{Allikad}

RKM - Eesti Rahvaluule Arhiivi käsikirjaline kogu, peamiselt aastaist 1947-1996.

RKM MGN - helisalvestused, Eesti Rahvaluule Arhiivi helikogu.

Geni.com. Hermine Elisabeth Jürgens. http://www.geni.com/people/Hermine-J\%C3\%B Crgens/6000000014683775560 - 23. jaanuar 2014.

\section{Kirjandus}

Annus, Endel (toim) 1995. Aasmann, Tiina \& Allpere, Andres \& Annus, Endel \& Kaunissaar, Külli \& Laidvee, Leida \& Miljan, Pärja \& Räim, Heino \& Siirman, Eve (koost). Eestikeelne raamat 1851-1900, 1, A-Q = Estnisches Buch 1851-1900, 1 = Estonian Book 1851-1900, Vol. 1 = Estonskaya kniga 1851-1900, T. 1. Eesti retrospektiivne rahvusbibliograafia. Tallinn: Eesti Teaduste Akadeemia Raamatukogu; Eestikeelne raamat 1851-1900, 2, R-Y = Estnisches Buch 1851-1900, 2 = Estonian Book 1851-1900, Vol. 2 = Estonskaya kniga 1851-1900, T. 2. Tallinn: Eesti Teaduste Akadeemia Raamatukogu. 
Annus, Endel (toim) 1993. Aasmann, Tiina (koost). Eestikeelne raamat 1901-1917, 1, A-P = Estnisches Buch 1901-1917, 1 = Estonian Book 1901-1917, Vol. 1 = Estonskaya kniga 1901-1917. T, 1.; Eestikeelne raamat 1901-1917, 2, R-Y = Estnisches Buch 19011917, 2 = Estonian Book 1901- 1917, Vol. 2 = Estonskaya kniga 1901-1917, T. 2. Tallinn: Eesti Teaduste Akadeemia Raamatukogu.

Grünfeldt, Inna 2004. Taimeteadjaga silmitsi. Virumaa Teataja, 30. oktoober (http:// www.virumaateataja.ee/2266539/kultuur-taimeteadjaga-silmitsi/Suuman - 3. november 2014).

Justkui 2002 = Baran, Anneli \& Hussar, Anne \& Õim, Asta \& Õim, Katre. Justkui. Eesti kõnekäändude ja fraseologismide andmebaas (http://www.folklore.ee/justkui/ 3. november 2014).

Jakobson, Carl Robert 1991. Kolm isamaakõnet. Faksiimileväljaanne käsikirjast. Tallinn: Eesti Raamat.

Jõesaar, Anu 1996. Äksi nõid sai hauakivi. Eesti Päevaleht, 2. juuli (http://epl.delfi.ee/ news/arvamus/aksi-noid-sai-hauakivi.d?id=50728163 -3 . november 2014).

Kulli, Jaanus 2002. Selgeltnägijast elu selgeks mõtestajaks. Elukiri 11 (http://arhiiv. elukiri.ee/index.php?main $=355 \&$ sess $=-3$. november 2014 ).

Kõiva Mare 1989. Aleksei Lesest ehk Tiitsu Seiust. Paar sammukest eesti kirjanduse uurimise teed. XII, lk 80-100. Tallinn: Eesti Raamat.

Kõiva, Mare 2010. The Last Minutes of our Earth. Folklore. Electronic Journal of Folklore 44, lk 132-156 (doi: 10.7592/FEJF2010.44.koiva).

Kõivupuu, Marju 2000. Rahvaarstid Võrumaalt. Noor ja vana Suri Hargla kihelkonnast. Tartu: Võro Instituut.

Loorits, Oskar 1951. Grundzüge des estnischen Volksglaubens II. Skrifter utgivna av kungl. Gustav Adolfs Akademien 18: 2. Lund: C. Blom.

Loorits, Oskar 1998 [1926-1928]. Liivi rahva usund I-III. Tartu: Eesti Keele Instituudi rahvausundi töörühma väljaanne (http://www.folklore.ee/rl/pubte/ee/lru/lru3/ - 3. november 2014).

Luhaäär, Ingvar 2014. Äksi nõiast Kirna Hundini: 50 aastat Eesti vaimseid maastikke Ingvar Luhaääre meenutustes. Vaimuvalgus 33. Postitatud 01.02.2014 (http://intuitiiv. blogspot.com/2014/02/aksi-noiast-kirna-hundini.html - 3. november 2014).

Paju, Aili 1994. Teadjanaine. Tartu: Aili Paju. [Teine, täiendatud trükk 2005.]

Piller, Meelis 1998. Äksi nõid läheb Eesti kultuurilukku. Eesti Ekspress nr 17 (437), 28. aprill (http://blog.ekspress.ee/Arhiiv/Vanad/1998/17/inimene1.html - 3. november 2014).

Soomere, Ilmar 1997. 800 parajuhtumit Eestis. Viljandi: Sünnimaa.

Suuman, Aleksander 1974. Äksi nõia meenutused. Looming 4, lk 600-602.

Suuman, Aleksander 2001. Äksi nõid meenutab. Looming 12, lk 1788. 
Talva, Helo 2011. Liivimaa nõia järeltulija mõõdab inimeste elu pikkust. Naised, 7. juuli (http://ajakirinaised.ee/persoon/3345/ - 3. november 2014).

Taal, Argo 1999. Nõia mälestus raiuti kivisse. Õhtuleht, 13. juuli (http://www.ohtuleht. ee/79423/noia-malestus-raiuti-kivisse - 3. november 2014).

Truus, Kalle (koost) 1999. Tundmatu Äksi nõid: Elulugu, pärimused, kommentaarid. Tallinn: Biorganica.

\section{Summary}

\section{The Witch of Äksi - Clairvoyant of the Soviet Period}

\section{Mare Kõiva}

Keywords: clairvoyant, Hermine Jürgens, modern witchcraft, patient narratives, divination narratives, witch of Äksi

This article is about the constellations in which communities accept extraordinary personalities and the traditional clairvoyant/witchcraft narratives. The person under discussion is the witch of Äksi, Hermine Elisabeth Jürgens (1892-1976), one of the best known Estonian 20th-century clairvoyants. In Estonian, the word nõid ('witch') is still used by the general public (a witch is a person with extraordinary powers, a healer, a wise(wo)man). During the Soviet period and also later, the term nõid was construed as an important keeper and interpreter of national knowledge. The article focuses on the life of the witch of Äksi and the corpus of narratives that talk about her, discussing the most common subtopics of narratives and motifs that have led to the folklorisation or narrativisation of her life. The narratives are divided into oral biographies, patient or client narratives (among which stories of divination stand out), and a smaller corpus, which contains the occurrences of the narrativisation of a person. The witch of Äksi was a city-born urbanite, who adapted to country life and unfamiliar socio-political circumstances. The narratives reflect the traditional duties of a witch/clairvoyant: looking for missing family members; searching for criminals or missing people in co-operation with the authorities; looking for stolen goods and animals; helping with matters of love and family relations; predicting one's future and fate; healing, and single political prophesies. 